\title{
Dispersal in a metapopulation of the critically endangered Danube Clouded Yellow butterfly Colias myrmidone: implications for conservation
}

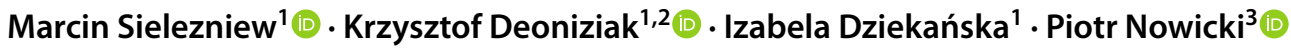

Received: 17 September 2018 / Accepted: 3 January 2019 / Published online: 18 January 2019

(c) The Author(s) 2019

\begin{abstract}
Colias myrmidone has suffered a dramatic decline in Europe, and now its occurrence is restricted to just a few countries. We investigated one of the last viable metapopulations (Knyszyn Forest, NE Poland), where the butterfly is almost completely dependent on forestry, inhabiting some clearings and young tree plantations rich in larval food plants (Chamaecytisus ruthenicus) and nectar resources. Intensive mark-recapture studies were performed in 2017 on eight occupied patches separated by $0.5-5 \mathrm{~km}$. The overall population size of imagoes in the second brood was calculated at about 750 individuals. Sex ratio was shown to be well-balanced and average residency was estimated at 5.6 days. Dispersal occurred mostly between neighbouring patches, and isolation of patches contributed to the high mortality of emigrants. The average distance covered during dispersal was significantly higher for males. However, females left small patches much more readily than males. These patches were probably used only as 'stepping stone' sites in dispersal. Restricted dispersal could be related to barriers created by forest stands but it is also not excluded that individuals living in an isolated metapopulation become increasingly sedentary and our results are an early warning sign. The most distant local population was clearly isolated, with hardly any immigration from the other populations. To maintain a network of more stable habitat patches some clearings should be left deforested and appropriately managed. However this goal is difficult to achieve under the current forestry rules and therefore (re)creation of habitats on other available open areas should be considered.
\end{abstract}

Keywords Life span $\cdot$ Mark-recapture $\cdot$ Sex-biased dispersal $\cdot$ Forestry $\cdot$ Mobility $\cdot$ Virtual migration model

\section{Introduction}

Many threatened European butterflies have suffered from habitat loss and/or fragmentation (Bubová et al. 2015). Moreover, most of them are dependent on seminatural biotopes whose (re)creation and persistence are related to human activities. They frequently thrive in metapopulation systems supported by unstable and scattered patches of habitat. Knowledge about the abilities of individuals to

Marcin Sielezniew

marcins@uwb.edu.pl

1 Institute of Biology, University of Bialystok, Ciołkowskiego 1J, 15-245 Białystok, Poland

2 Department of Behavioural Ecology, Adam Mickiewicz University, Umułtowska 89, 61-614 Poznań, Poland

3 Institute of Environmental Sciences, Jagiellonian University, Gronostajowa 7, 30-387 Kraków, Poland cross an unfavourable matrix is vital for the effective conservation of local populations facing constant environmental changes (Shreeve and Dennis 2011). For this reason butterfly dispersal has recently drawn much attention, and numerous studies have been undertaken using several different direct and indirect (i.e. genetic) methods. As a result butterflies are probably the best studied animals in this respect, and considered a model group (Thomas and Hanski 1997; Dover and Settele 2009; Hoverstadt and Nieminen 2009; Stevens et al. 2010b, 2012).

Multi-site studies using the mark-release-recapture (MRR) method show that general dispersal abilities arise from species-specific features or even intraspecific variation (Merckx et al. 2003; Stevens et al. 2010a). Emigration from a habitat patch may be negatively correlated with its size (Hill et al. 1996) and positively correlated with local population density (Nowicki and Vrabec 2011), but is also affected by weather (Cormont et al. 2011), habitat boundaries (Merckx et al. 2003), surrounding matrix (Ricketts 2001), isolation 
(Hanski et al. 2004; Schtickzelle et al. 2006; Bonelli et al. 2013) and habitat quality (Baguette et al. 2011), which can change over time.

Typical examples of ephemeral biotopes, which are more or less isolated from each other, are forest clearings. In the past they could appear naturally as a result of fire or windfall but nowadays they are mostly of anthropogenic origin, i.e. related to logging. In silviculture, new clearings are usually quickly afforestrated and only rarely left for natural succession. Both processes sooner or later lead to the disappearance of open patches. Nevertheless, clearings are often characterized by a high diversity of butterflies (especially compared to dense stands of planted trees-Schmitt 2003; Viljur and Teder 2016), including species threatened by extinction on a regional or European scale (Bergman 2001). Simultaneously it is worth emphasizing that woodland butterflies are showing a substantial decline across Europe, in contrast to e.g. woodland birds which situation is more or less stable (Van Swaay et al. 2006).

An intensively managed forest area in NE Poland is the home of one of the last viable European metapopulations of the Danube Clouded Yellow butterfly Colias myrmidone. The species is one of the most endangered butterflies, not only in Europe (Van Swaay et al. 2010; Maes et al. 2019) but also globally, as its distribution range is almost entirely included within the continent (Marhoul and Dolek 2012). It has suffered a dramatic decline on a continental scale and now its occurrence is restricted to just a few countries. Previous studies on C. myrmidone concerned disappearing (and now extinct) populations in Germany (Dolek et al. 2005; Freese et al. 2005), as well as Romanian sites still considered as strongholds of the species in Central Europe (Szentirmai et al. 2014).

However, little is known about the ecology of lowland populations from the northern part of the distribution range, i.e. Poland, where it has survived only in two areas in the north-east. In one of them Colias myrmidone is at the moment totally dependent on forestry and hence seems to be an ideal model species for studies of dispersal in woodlands. Using the MRR method we aimed to investigate the demography and mobility of this unique metapopulation system to learn the factors affecting its functioning and possibly develop some conservation recommendations which would be important in increasing the chances of its survival in the longer perspective.

\section{Materials and methods}

\section{Study species}

Danube Clouded Yellow Colias myrmidone shows a European type of distribution range. In the past it used to be distributed from southern Germany through Central Europe, Ukraine and Russia to the southern part of the Ural Mts. and NW Kazakhstan. Due to many local extinctions the butterfly is now classified as endangered (EN) in Europe and critically endangered (CR) in the European Union (Van Swaay et al. 2010), where it has survived probably only in six countries at most (Maes et al. 2019). Moreover C. myrmidone is listed in Annexes II and IV of the Habitats Directive and therefore is a priority species in the conservation management of Natura 2000 sites. Deterioration and habitat losses, as well as climate change, are considered as the main causes of the dramatic decline (Konvička et al. 2008; Marhoul and Dolek 2012; Szentirmai et al. 2014). It is predicted that more than $95 \%$ of the currently suitable climate niches may no longer be suitable in 2080 (Settele et al. 2008).

Poland, through which the northern limit of the occurrence of the species currently passes, is a typical example of the rapid decline of the species. After 1986, C. myrmidone has been recorded in more than one hundred $10 \times 10 \mathrm{~km}$ UTM grid cells. At the moment only six of them are still occupied and the butterfly is observed only in the lowlands in two areas in the NE part of the country, i.e. at the former military training ground Czerwony Bór and in the Knyszyn Forest. In the past some populations were present also in the south of the country in the highlands (Sielezniew 2012 and unpublished). Those sites could be similar to Romanian sites where the butterfly is restricted to highlands and submountainous areas (altitude 400-950 m) (Szentirmai et al. 2014).

The butterfly appears in two or three broods depending on locality and/or season. Eggs are laid singly on the upper side of the leaves of sun-exposed sprouts of Chamaecytisus plants (C. austriacus, $C$. ratisbonensis, $C$. ruthenicus, $C$. supinus and $C$. triflorus are mentioned across Europe) growing in dense patches. Pupation takes place on food plants or on vegetation nearby. The medium size caterpillars overwinter (Marhoul and Dolek 2012; Sielezniew 2012).

\section{Study area}

The studied metapopulation of Colias myrmidone inhabited the Knyszyn Forest, which is one of the Prime Butterfly Areas in Poland with 102 species recorded, i.e. about 2/3 of the national fauna. As many as 14 of them are listed on the Red List of European Butterflies, and eight are enumerated in the Annexes of Habitats Directive (Klimczuk 2011; Sielezniew and Nowicki 2017; Sielezniew and Wołkowycki 2018).

Colias myrmidone used to be widespread in the Knyszyn Forest (Klimczuk 2011), but its range has contracted over the last two decades (Sielezniew unpublished). At the moment it only inhabits forest clearings and is totally dependent on forestry. The local larval food plant i.e. Chamaecytisus ruthenicus is present in some stands, especially older and 
lighter ones. After logging, which increases sun exposure considerably, the plant may grow lush and cover the ground extensively on some patches. These open biotopes disappear following forest renewal, and the speed of this process depends on local conditions and the species composition of planted trees as well as the management of plantations, e.g. unfenced patches are grazed by wild game and therefore remain suitable for longer times compared to those protected by fencing.

Studies were performed on eight patches of the species habitat defined as open sun-exposed vegetation fragments with $C$. ruthenicus food plants present. All the patches were occupied by $C$. myrmidone in the year of our study, even though local numbers of butterflies were very low in some cases (see "Results"). The patches were named with capital letters from A to $\mathrm{H}$, and separated by a distance of $0.5-5 \mathrm{~km}$ (Fig. 1). They were located in the eastern part of the Knyszyn Forest. The patch size varied from 0.1 to 2.55 ha and the total investigated area was $9.77 \mathrm{ha}$. The area was flat or slightly inclined, with $\mathrm{S}$ exposures. Patches were quite diverse and included different stages of forest development as well as recently logged ones. Two were related to dirt road verges $(\mathrm{C}$ and $\mathrm{F})$ and one $(\mathrm{G})$ was situated under the electricity line (Table 1; Fig. 1).

In the year of study the eight aforementioned patches were the only known sites with the $C$. myrmidone habitat in the Knyszyn Forest, which have been regularly surveyed with the aim to identify all the local populations of the butterfly. However due to dynamic nature of landscape related to intensive forestry and the overall large area of the region ( $>1000$ ha) there is no absolute certainty that we investigated all currently existing breeding sites.

\section{Data collection}

We used a MRR study to estimate population size, adult daily survival and residence times, and exchange of individuals between habitat patches. The metapopulation was sampled in 2017 in the second brood on 23 occasions between 27 July and 1 September. The sampling covered the entire flight period of the second brood of the focal species, and the sites were visited almost every day if the weather was

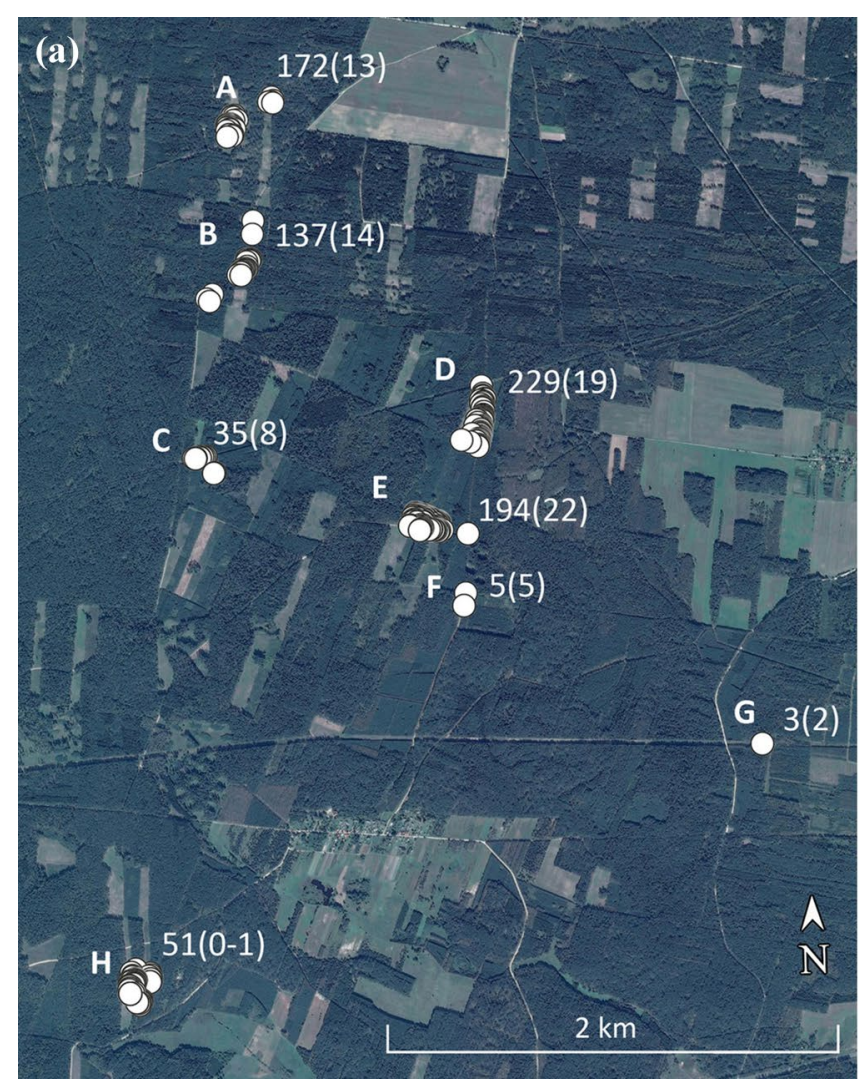

Fig. 1 Orthophotomap of the study site in 2016, and the distribution of C. myrmidone captures in 2017 (a). The capital letters depict local populations inhabiting distinct habitat patches. The numbers indicate estimated population size (according to the CJS model) and the estimated seasonal number of immigrants are given in parentheses. The

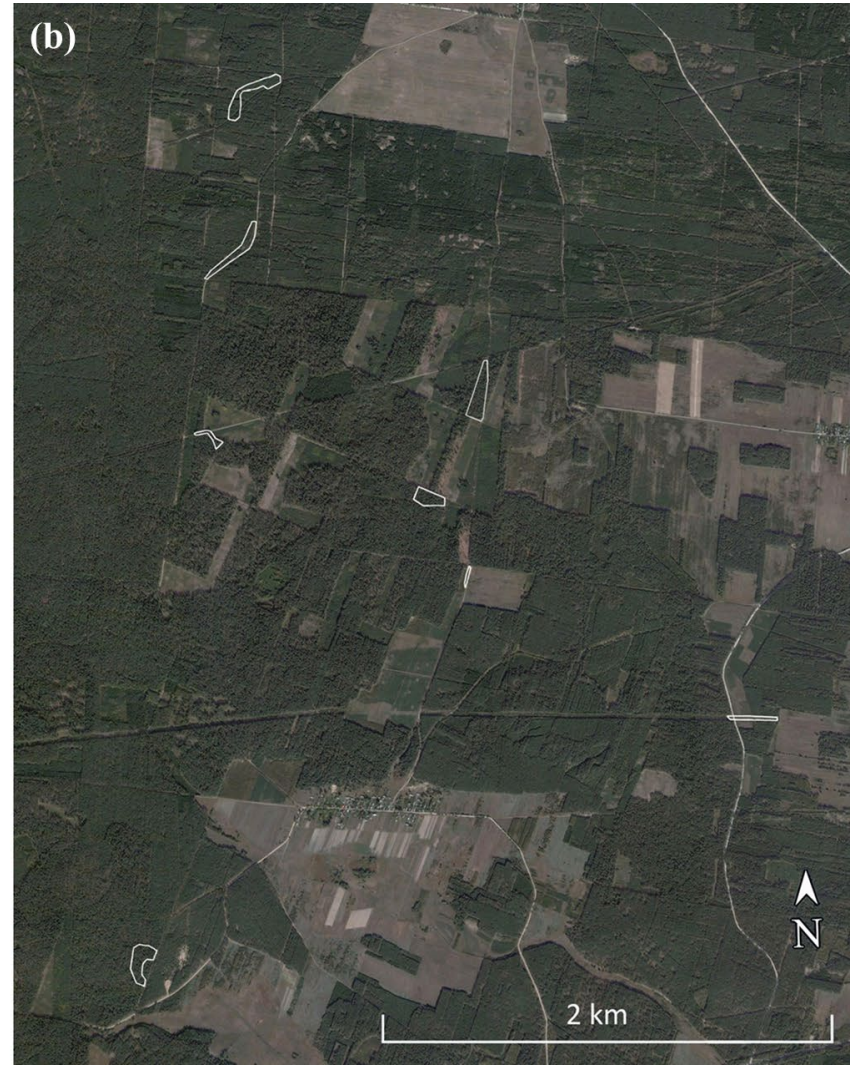

orthophotomap of the site in 2003 (b) is also presented so as to document the fact that almost the whole area now occupied by the butterfly (white empty polygons) was covered by forest in the past. Source of orthophotomaps Image Landsat/Copernicus and CNES Airbus (acquired by Google Earth, Image @ 2018 Digital Globe) 
Table 1 Characteristics of habitat patches occupied by C. myrmidone in the Knyszyn Forest

\begin{tabular}{|c|c|c|c|c|}
\hline Patch & Area (ha) & Altitude (m) & Biotope & $\begin{array}{l}\text { Food } \\
\text { plant } \\
\text { cover }(\%)\end{array}$ \\
\hline A & 1.51 & $170-180$ & New clearing & $5-10$ \\
\hline B & 1.16 & $168-175$ & New clearing & $5-10$ \\
\hline $\mathrm{C}$ & 0.31 & $183-188$ & New clearing and road verges & $<5$ \\
\hline $\mathrm{D}$ & 1.95 & $181-187$ & New clearing and partially afforested ca $10 \mathrm{yrs}$. ago & $10-20$ \\
\hline $\mathrm{E}$ & 1.84 & $178-187$ & New clearing neighbouring and area left for natural succession of birch & $5-10$ \\
\hline $\mathrm{F}$ & 0.10 & $174-179$ & Road verges & $<5$ \\
\hline G & 0.35 & $175-176$ & Strip of land under electricity line temporarily cleared of trees and shrubs & $<5$ \\
\hline $\mathrm{H}$ & 2.55 & $168-184$ & New clearing and area afforestrated ca 8 yrs. ago or left for natural succession & $5-10$ \\
\hline
\end{tabular}

favourable (i.e., sunny and not very windy), between $10 \mathrm{am}$ and $5 \mathrm{pm}$. One or two people spent about $2-4 \mathrm{~h}$ in the field during each sampling day. Almost every time all patches were explored one by one. Butterflies were captured with an entomological net, marked on the underside of their hindwings with unique identity numbers using a fine-tipped waterproof pen, and then immediately released at the place of capture. Different codes were applied for different habitat patches to avoid confusion. Date, time and GPS coordinates of each (re)capture, as well as the sex and ID number of each butterfly, were recorded. Additionally the behaviour of every encountered individual was recorded.

\section{Analysis}

Using the mark-recapture data collected we estimated the seasonal size of the entire metapopulation of Colias myrmidone, as well as the sizes of its local populations at the investigated habitat patches, with the Jolly-Seber model (Arnason and Schwarz 1999) in the Mark 8.0 program (White and Burnham 1999). The model selection procedure, relying on the Akaike Information Criterion corrected for small sample size (AICc) (Hurvich and Tsai 1989), clearly indicated that the best performing model variant was invariably the one assuming a constant and sex-independent survival rate $(j)$, but constant and sex-dependent capture probabilities $(p)$. Consequently, due to differences in the catchability of each sex, the population sizes were first obtained separately for males and females, and then summed. The mean adult life span was estimated from the survival rate as $e=(1-j)^{-1}-0.5$ (Nowicki et al. 2005). Additionally we calculated the temporal fragmentation index, i.e., ratio of flight period length to adult life span, which is considered as one of the indicators of species vulnerability. Higher values of this index are typically related to extended asynchronous emergence of relatively short lived adult individuals, and they imply the reduction of effective population size especially in smaller populations (Bubová et al. 2016).

In the cases of patches $\mathrm{C}, \mathrm{F}$ and $\mathrm{G}$, where the numbers of captures were too low to allow the application of the Jolly-Seber model, their seasonal population sizes were derived as the numbers of captured butterflies multiplied by 2.5 , with the assumption that ca. $40 \%$ individuals were surveyed during the season, as at all the other sites.

In addition, we investigated the dispersal of butterflies among the investigated patches with the Virtual Migration (VM) model (Hanski et al. 2000), which represents a wellestablished standard for this purpose. As a detailed description of the model can be found elsewhere (e.g. Hanski et al. 2000; Petit et al. 2001; Bonelli et al. 2013), here we only briefly outline its application. The model defines the dispersal of individuals within a metapopulation with six parameters, including (i) mortality in habitat patches $\left(\mu_{\mathrm{p}}\right)$; (ii) emigration propensity $(\eta)$; (iii) emigration scaling with patch area $\left(\zeta_{\mathrm{em}}\right)$ ); (iv) immigration scaling with target patch area $\left(\zeta_{\mathrm{im}}\right)$; (v) scaling of dispersal mortality with natal patch connectivity $(\lambda)$; and (vi) distance dependence of dispersal $(\alpha)$. Emigration propensity is defined as daily emigration rate scaled to an imaginary 1 -ha patch. The actual emigration rate is assumed to be negatively related to patch area, while the immigration rate is assumed to be positively related to it, and thus $\zeta_{\mathrm{em}}$ and $\left(\zeta_{\mathrm{im}}\right)$ parameters representing the exponents of the power functions have negative and positive values respectively. Dispersal mortality is modelled to decrease sigmoidally with the connectivity (i.e. the inverse measure of patch isolation as adopted by Hanski 1994) of a natal patch, and the square root of $\lambda$ reflects patch connectivity, for which half the emigrants die during dispersal. Distance dependence parameter defines the dispersal kernel. We used the negative exponential function (NEF) as the kernel (as in Hanski et al. 2000), which fitted our data substantially better than the inverse power function (IPF) recommended as an alternative e.g. by Fric et al. (2010). In the case of NEF 
the mean dispersal distance (measured in $\mathrm{km}$ ) corresponds to $1 / \alpha$.

The dispersal parameter values and their $95 \%$ confidence intervals were estimated with the VM2 and VMCL2 programs respectively (Hanski et al. 2000). The estimates were produced separately for both sexes as well as jointly for all individuals. With generally few intersexual differences in most cases (see "Results"), parameter estimates for all individuals were subsequently applied, together with the seasonal population size estimates of all the local populations, to simulate the exchange of butterflies among them using the VMSIM program (Hanski et al. 2000). This made it possible to assess the absolute numbers of dispersing individuals, including the unsuccessful dispersers as well as the successful immigrants to each population. We conducted 100
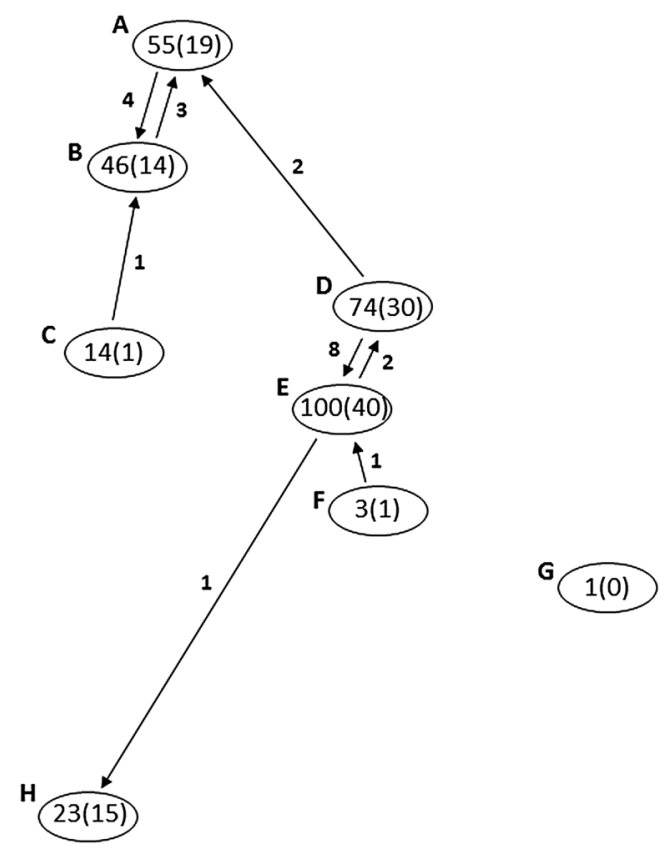

Fig. 2 Outline of the study system in which MRR survey of $C$. myrmidone was performed in 2017. The numbers in ovals indicate the numbers of marked individuals and recaptures (in parentheses) within eight habitat patches $(\mathbf{A}-\mathbf{H})$. The numbers of recorded movements are given next to the arrows showing direction of flights simulation runs, and calculated the mean disperser numbers and their standard errors based on the simulation outcomes.

\section{Results}

We captured and marked a total of 314 individuals (162 males and 152 females). Only one individual was marked at patch $\mathrm{G}$ and as many as 100 at patch E (Fig. 2). Among females two forms were distinguished i.e. andromorphic (orange) and gynomorphic (pale yellow) ones. They were recorded in similar proportions (73 and 79 individuals respectively). Since we did not find any differences in any of the investigated parameters between the two forms, we pooled the data for all females. More than one-third of marked individuals, i.e. 120 (38.2\% of males and 39.0\% of females) were recaptured on subsequent days after marking. The highest number of recaptured individuals was observed at patch E (Fig. 2).

The mean number of days between the first and last capture was 7.05 for males and 6.63 for females, whereas the maximum duration between captures of an individual reached 27 and 17 days respectively. The daily survival rate obtained with the Jolly-Seber model was 0.84 (95\% CI 0.81-0.86) and was consistent with within-patch mortality estimated at 0.15 in the VM model (Table 2). It corresponded to the estimated adult residency time of 5.58 days (95\% CI 4.82-6.46 days) for the entire metapopulation, ranging from 4.23 days (95\% CI 3.37-5.35 days) at patch $\mathrm{E}$ to 8.58 days ( $95 \%$ CI $4.83-15.58$ days) for $\mathrm{H}$. Taking into consideration the recorded flight period ( 36 days) the temporal fragmentation index was estimated at 6.45 .

The mean capture probability was slightly higher in males $(0.26 \pm 0.03$; $95 \%$ CI: $0.20-0.31)$ than in females $(0.24 \pm 0.03 ; 95 \%$ CI $0.19-0.30)$. Protandry was detected, i.e. in the first ten days of the flight period more males than females were caught (Fig. 3). The seasonal metapopulation size was estimated at 757 adults (95\% CI 650-882), with a fairly well-balanced sex ratio, i.e., 374 males (95\% CI 311-450) and 383 females (95\% CI 301-487). Population size estimates for particular patches varied from three (patch G) to 229 individuals (patch D) (Fig. 1).

Table 2 Dispersal parameter estimates (with their 95\% CI) of the VM model for the investigated metapopulation of Colias myrmidone

\begin{tabular}{lccc}
\hline Parameter & Males & Females & All individuals \\
\hline Mortality in patch & $0.152(0.111-0.183)$ & $0.152(0.128-0.178)$ & $0.152(0.136-0.177)$ \\
Emigration rate for 1 ha patch & $0.096(0.046-0.182)$ & $0.088(0.031-0.192)$ & $0.083(0.048-0.170)$ \\
Scaling of emigration with patch size & $-1.966(-2.696$ to -1.276$)$ & $-6.559(-6.912$ to -4.361$)$ & $-2.127(-2.636$ to -1.324$)$ \\
Distance-dependence in dispersal & $1.329(0.593-2.233)$ & $4.894(2.421-5.287)$ & $1.721(0.729-2.520)$ \\
Scaling of mortality during dispersal & $0.866(0.206-2.832)$ & $0.109(0.006-0.329)$ & $0.629(0.163-3.317)$ \\
Scaling of immigration with patch size & $0.453(0-1.020)$ & $0.416(0-1.139)$ & $0.416(0-1.139)$ \\
\hline
\end{tabular}




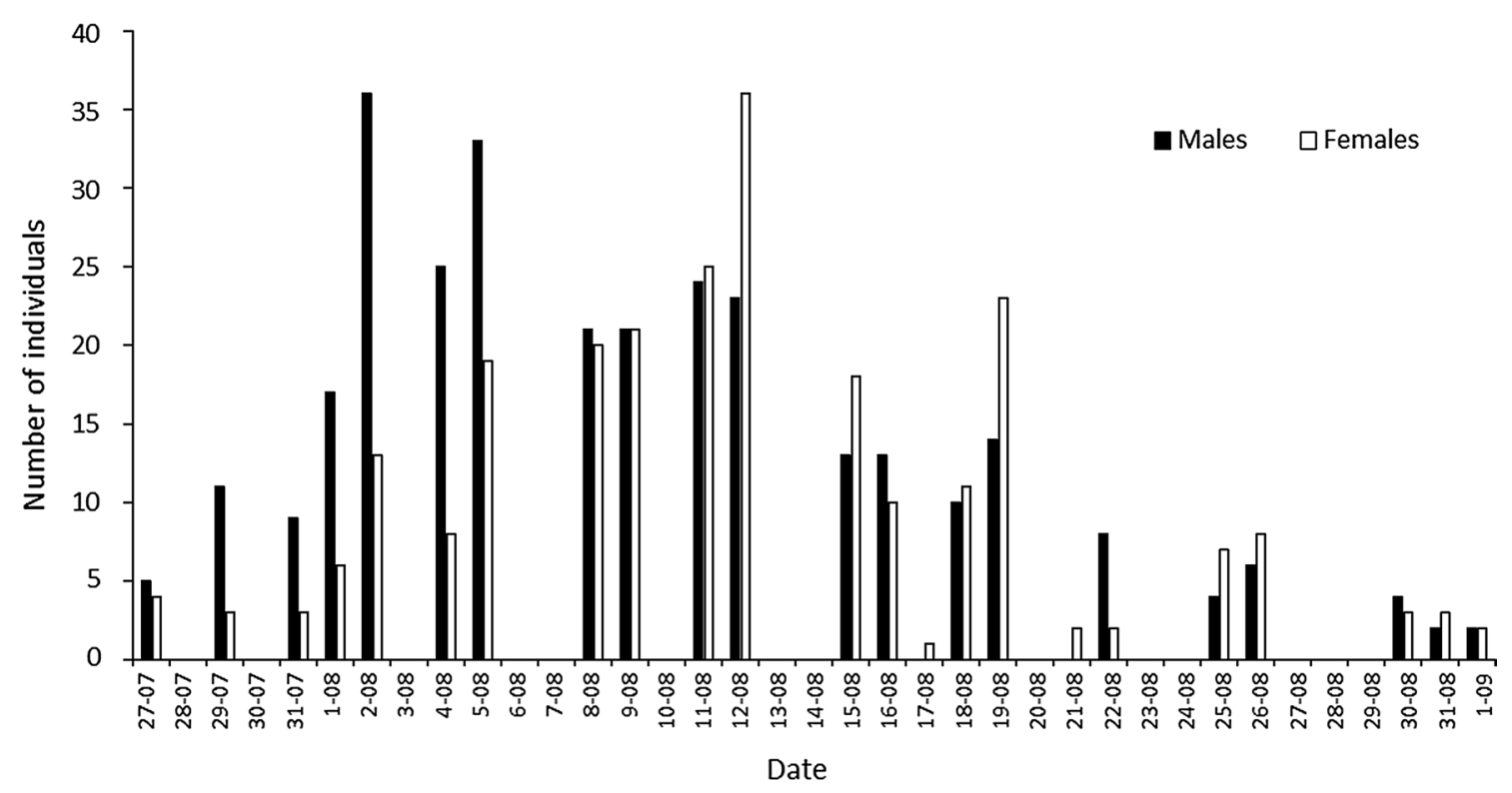

Fig. 3 Dynamics of daily numbers of males and females (re)captured throughout the flight period of the second brood in 2017. It should be noted that no butterflies were observed after 1 September

We recorded 310 and 247 behavioural observations for males and females respectively. The majority of captured males (61.3\%) were spotted when flying and the second most frequent activity was nectaring (33.5\%). Other observations involved resting (3.9\%) and mating/courtship (1.2\%). In turn, for females the proportion of flying and nectaring individuals was very similar (38.9\% and $41.7 \%$ respectively). Oviposition was then observed in the case of $12.6 \%$ spotted females, whereas $5.3 \%$ were observed resting and $1.6 \%$ during mating/courtship. The difference in proportions of flight and non-flight activities between males and females were highly significant (Chi square test, $\mathrm{p}<0.00001, c^{2}=25.9$ ). The main nectar plant was Knautia arvensis for both sexes (57 and 53\% of records for males and females respectively). Other frequently used plants were Jasione montana, Hieracium pilosella, Senecio spp., Centarurea spp., and Scabiosa spp.

We recorded 22 movements between habitat patches (Fig. 2). However, the total number of dispersal events in the metapopulation estimated through the VM model simulations reached $163.1 \pm 4.3$ including $83.2 \pm 2.7$ and $79.9 \pm 1.8$ successful and unsuccessful cases respectively. Dispersal occurred mostly between neighbouring patches. The highest estimated number of immigrants based on the simulations (22) was predicted for patch E, situated between two other patches lying in close proximity. In contrast, the most distant local population $(\mathrm{H})$ was clearly isolated from the others. Its estimated seasonal number of immigrants was only $0-1$ (Fig. 1). In two of the three smallest patches (F and $\mathrm{G})$, where the larval food plants were very rare, virtually all individuals were immigrants. At the third small patch (C), $C$. myrmidone was observed exclusively in the first part of the flight period and only very fresh individuals (i.e. probably caught shortly after eclosion) were recorded (Fig. 1).

Emigration propensity was similar for both sexes (estimated at the level of around 10\% individuals per day) and was much higher in the case of smaller patches (Table 2). However, the actual emigration increased greatly with decreasing patch size (Fig. 4), as indicated by the relatively high values of the emigration scaling estimates (Table 2), especially in females which implies that females left small patches more readily than males. Isolation of patches contributed to the high mortality of emigrants and reached 1 for patch $\mathrm{H}$ (Fig. 4). Average distance covered during dispersal was significantly higher for males $(752 \mathrm{~m}, 95 \% \mathrm{CI}$ 448-1686) than for females (204 m; 95\% CI 189-413).

\section{Discussion}

The overall population size of imagos in the second brood was estimated at about 750 individuals, which is very similar to figures obtained for the best studied Romanian site, where, however, a much larger area was occupied (Szentirmai et al. 2014). The overall average residency estimated for individuals in our metapopulation (5.6 days) was higher than in the case of Romania (3.5) and as a consequence the temporal fragmentation was somewhat lower (6.5 and 7.5 respectively). Nevertheless, both values are rather low when compared to those obtained for other threatened European butterflies (cf. Bubová et al. 2016), which may suggest that 
Fig. 4 Daily emigration rate (black circles) and mortality of emigrants (white circles) in relation to patch size

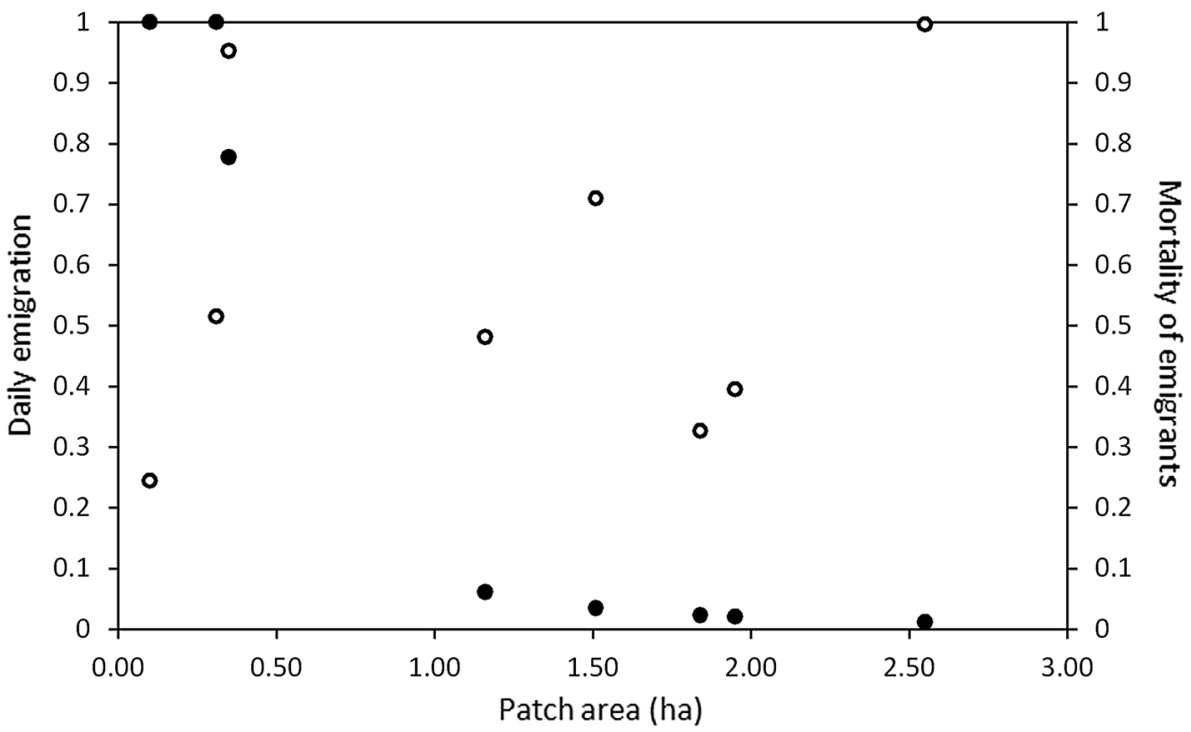

decreased effective population size and thus reduced viability is still not a serious problems in the presently studied metapopulation.

We noted that males spent more time in flight, which is consistent with the observations of Kingsolver (1983) concerning Colias philodice, as well as the results of most other studies on butterflies (Hovestadt and Nieminen 2009). However we observed that females were also quite active in searching for plants appropriate for oviposition and simultaneously were somewhat easier to catch as they flew a bit slower compared to males. Both sexes frequently visited flowers and were quite easy to spot during nectaring. Moreover the studied patches of habitats were relatively small, which also probably positively affected the encounter probability of both sexes.

The average distance covered during dispersal was significantly lower for females. Such differences, which were observed also in the case of another endangered European butterfly Coenonympa oedippus (Örvössy et al. 2013) and some other species (Kallioniemi et al. 2014), may be explained by the sex-specific effects of an unfavourable matrix on flight, as was shown for two Boloria species (Turlure et al. 2011). The pattern revealed in our studies may suggest restricted colonization abilities, yet simultaneously show that gene flow still occurs among occupied patches.

In the present studies, females left small patches much more readily than males. Sex-biased emigration from small habitats is reported for Boloria eunomia (Petit et al. 2001) and Iolana iolas (Rabasa et al. 2007), but in both cases males were more willing to leave. Nevertheless, it is important to emphasize that a dispersal decision is triggered by several factors. Females frequently leave patches with high male density to avoid harassment (Petit et al. 2001), and this could be the case here.
Small patches in the presently studied system were probably used only as 'stepping stone' sites in dispersal. Indeed in those patches butterflies were recorded almost exclusively only at the beginning of the flight period, probably shortly after eclosion. This finding is very important in the context of species conservation, as implies that $C$. myrmidone needs more space compared to other species of xerothermophilous butterflies inhabiting woodlands. Many species are supported by corridor-like habitat structures i.e. road verges, railway embankments or stripes under electricity lines and over gas pipes. In the Knyszyn Forest a typical example of a species with such preferences is e.g. Phengaris arion (Sielezniew unpubl.). The present study suggest that such relatively narrow open patches are suitable at the most for the larval development of $C$. myrmidone, but are definitely not appropriate for mating. It could be related to the behaviour of males, which are patrollers actively searching for females and they tend to fly fast across open patches.

There is no doubt that $C$. myrmidone has survived in the Knyszyn Forest only thanks to forestry based on large scale logging. This is a kind of paradox as intensive forest management is the cause of the decline of many butterfly species in Europe (Bubová et al. 2015). A few hectares of clearings were replaced in some woodlands in Poland by group selection cutting. The latter practice does not create enough space for species like $C$. myrmidone, which is not a typical forest species using e.g. the coppiced woodlands as Melithaea athalia (Warren 1991), Lopinga achine (Bergman 2001) or Euphydryas maturna (Dolek et al. 2018).

In general, $C$. myrmidone was shown to be a less mobile species than it was expected taking into consideration its size and records of some individuals which were reported in past far away from known colonies. The quick range contraction observed in recent decades may be negatively correlated 
with dispersal abilities. Taking into consideration our data, it seems that at the moment selection against mobility is observed and populations possibly become more and more closed due to habitat fragmentation (cf. Bonelli et al. 2013). Studies of the last German sites in Bavaria indicated that the species was extremely sedentary, with no movements between local populations (Dolek et al. 2005). Therefore, isolation of the $\mathrm{H}$ patch, which was also characterized by the highest residency time, could be an early warning sign for the future functioning of the metapopulation. Besides, it is likely that forest stands are much more effective barriers for dispersal than e.g. arable land (Skórka et al. 2013).

Therefore the maintenance of a network of suitable habitat patches which are large enough and located in close proximity to each other is particularly important for the survival of the entire metapopulation system. Unfortunately effective conservation management is difficult at the moment, taking into consideration the realities of forestry in Poland. Larval food plants are present in some stands, especially not very dense ones, but usually they are rather weak and scarce. After logging the food plant starts its prosperity period, which lasts until plantings are a few meters high. According to local foresters the kind of practice favouring the continuous re-creation of $C$. myrmidone habitats will be continued for the next 20-30 years in the region, but afterwards it will most likely be ceased because all forest stands will be too young for logging. Hence, it is necessary to introduce targeted management intended for the conservation of $C$. myrmidone, namely establish a network of open habitats, managed to sustain a high density of larval and nectar food plants. The ideal solution would be leaving some selected clearings rich both in larval food plants and nectar plants without afforestation and introducing management beneficial for the butterfly. The management action should involve the removal of tree seedlings and if necessary also mowing of the land fragments overgrowing with invasive plants (e.g. goldenrods), other tall herbs or grasses. However, at the moment this is unlikely taking into consideration forestry regulations, which only allow some parts of new clearings to be left for natural succession but not their maintenance as open habitats. These clearings are suitable for the butterfly for much longer compared to afforested ones. The recommendation for those young tree plantations which are rich in larval food plants should be to manage them (mostly through mowing) with the patches of $C$. ruthenicus left untouched.

It seems highly desirable to consider the (re)creation of suitable habitats in areas that are not subject to forestry rules, i.e. are not classified as woodlands. Some wide power-line corridors which are known as important biotopes for butterflies in forest landscapes (Berg et al. 2016) as well as some open areas adjacent to the forest may be relevant for such plans. The key actions should include planting C. ruthenicus and favourite nectar plants. Further studies on habitat requirements of the larval food plant are also needed in order to reveal why it grows numerously in some forest stands while it is scarce or absent in others. As a consequence only some clearings and young tree plantations are inhabited by the butterfly and numerous open areas are unoccupied, as shown in Fig. 1b. This information, accompanied with the knowledge on the minimum conditions necessary for the long-term persistence of local populations of $C$. myrmidone, its oviposition preferences and factors affecting larval survival, would be complementary to our findings.

To conclude, the conservation of the last remaining metapopulations of $C$. myrmidone in Poland poses quite specific challenges. In the Czech Republic intensification of mowing related to agri-environmental schemes is considered the main reason for the extinction of the species from its former stronghold in the White Carpathians (Konvička et al. 2008), and in Romania high grazing pressure is the most important negative factor (Szentirmai et al. 2014). In Poland almost all threats are related to forestry, which is, however, simultaneously responsible for the creation of potential habitats.

Acknowledgements This article has received financial support from the Polish Ministry of Science and Higher Education under the subsidy for maintaining the research potential of the Faculty of Biology and Chemistry, University of Bialystok. The analysis was supported by the Polish National Science Centre (grant number DEC-2013/11/B/ NZ8/00912). Sarah Łuczaj made linguistic improvements on the manuscript. The Regional Director for Environmental Protection in Białystok provided permission for the mark-release-recapture sampling of $C$. myrmidone. Two anonymous reviewers made valuable comments on the manuscript.

\section{Compliance with ethical standards}

Conflict of interest The authors declare that they have no conflict of interest.

Open Access This article is distributed under the terms of the Creative Commons Attribution 4.0 International License (http://creativeco mmons.org/licenses/by/4.0/), which permits unrestricted use, distribution, and reproduction in any medium, provided you give appropriate credit to the original author(s) and the source, provide a link to the Creative Commons license, and indicate if changes were made.

\section{References}

Arnason AN, Schwarz CJ (1999) Using POPAN-5 to analyse banding data. Bird Study 46:157-168

Baguette M, Clobert J, Schtickzelle N (2011) Metapopulation dynamics of the bog fritillary butterfly: experimental changes in habitat quality induced negative density-dependent dispersal. Ecography 34:170-176

Berg Å, Bergman KO, Wissman J, Żmihorski M, Öckinger E (2016) Power-line corridors as source habitat for butterflies in forest landscapes. Biol Conserv 201:320-326 
Bergman K-O (2001) Population dynamics and the importance of habitat management for the conservation of the butterfly Lopinga achine. J Appl Ecol 381:303-1313

Bonelli S, Vrabec V, Witek M, Barbero F, Patricelli D, Nowicki P (2013) Selection on dispersal in isolated butterfly metapopulations. Popul Ecol 55:469-478

Bubová T, Vrabec V, Kulma M, Nowicki P (2015) Land management impacts on European butterflies of conservation concern: a review. J Insect Conserv 19:805-821

Bubová T, Kulma M, Vrabec V, Nowicki P (2016) Adult longevity and its relationship with conservation status in European butterflies. J Insect Conserv 20:1021-1032

Cormont A, Malinowska AH, Kostenko O, Radchuk V, Hemerik L, Wallis-DeVries MF, Verboom J (2011) Effect of local weather on butterfly flight behavior, movement, and colonization: significance for dispersal under climate change. Biodivers Conserv 20:483-503

Dolek M, Freese A, Geyer A, Stetter H (2005) The decline of Colias myrmidone at the western edge of its range and notes on its habitat requirements. Biologia 60:607-661

Dolek M, Kőrösi Á, Freese-Hager A (2018) Successful maintenance of Lepidoptera by government-funded management of coppiced forests. J Nat Conserv 43:7-84

Dover J, Settele J (2009) The influences of landscape structure on butterfly distribution and movement: a review. J Insect Conserv 13:3-27

Freese A, Dolek M, Geyer A, Stetter H (2005) Biology, distribution, and extinction of Colias myrmidone (Lepidoptera, Pieridae) in Bavaria and its situation in other European countries. J Res Lep 38:51-58

Fric Z, Hula V, Klimova M, Zimmermann K, Konvicka M (2010) Dispersal of four fritillary butterflies within identical landscape. Ecol Res 25:543-552

Hanski I (1994) A practical model of metapopulation dynamics. J Anim Ecol 63:151-162

Hanski I, Alho J, Moilanen A (2000) Estimating the parameters of survival and migration of individuals in metapopulations. Ecology 81:239-251

Hanski I, Erälahti C, Kankare M, Ovaskainen O, Siren H (2004) Variation in migration rate among individuals maintained by landscape structure. Ecol Lett 7:958-966

Hill JK, Thomas CD, Lewis OT (1996) Effects of habitat patch size and isolation on dispersal by Hesperia comma butterflies: implications for metapopulation structure. J Anim Ecol 65:725-735

Hovestadt T, Nieminen M (2009) Costs and benefits of dispersal in butterflies. In: Settele J, Shreeve T, Konvicka M, Van Dyck H (eds) Ecology of butterflies in Europe. Cambridge University Press, Cambridge, pp 97-106

Hurvich CM, Tsai C (1989) Regression and time series model selection in small samples. Biometrika 76:297-307

Kallioniemi E, Zannese A, Tinker JE, Franco AMA (2014) Inter-and intra-specific differences in butterfly behaviour at boundaries. Insect Conserv Divers 7:232-240

Kingsolver JG (1983) Ecological significance of flight activity in Colias butterflies: implications for reproductive strategy and population structure. Ecology 64:546-551

Klimczuk P (2011) Butterflies (Lepidoptera: Hesperioidea, Papilionoidea) of the Knyszyńska Forest (Puszczy Knyszyńskiej) and adjacent woodland areas of Białystok. Nat J 44:197-217

Konvička M, Beneš J, Č́ížek O, Kopeček F, Konvička O, Vítaz L (2008) How too much care kills species: grassland reserves, agrienvironmental schemes and extinction of Colias myrmidone butterfly from its former stronghold. J Insect Conserv 12:519-525

Maes D, Verovnik R, Wiemers M, Brosens D, Beshkov S, Bonelli S, Buszko J, Cantú Salazar L, Cassar LF, Collins S, Dincă V, Djuric
M, Dusej G, Elven H, Franeta F, Garcia Pereira P, Geryak Y, Goffart P, Gór A, Hiermann U, Höttinger H, Huemer P, Jakšić P, John E, Kalivoda H, Kati V, Komac B, Kőrösi A, Kulak AV, Kuussaari M, L'Hoste L, Lelo S, Mestdagh X, Micevski N, Mihut S, Monasterio León Y, Munguira ML, Murray T, Nielsen PS, Ólafsson E, Õunap E, Pamperis L, Pavlíčko A, Pettersson LB, Popov S, Popović M, Ryrholm N, Šašić M, Pöyry J, Savenkov N, Settele J, Sielezniew M, Sinev S, Stefanescu C, Švitra G, Tammaru T, Tiitsaar A, Tzirkalli E, Tzortzakaki O, van Swaay CAM, Viborg AL, Wynhoff I, Zografou K, Warren MS (2019) Integrating national Red Lists for prioritising conservation actions for European butterflies. J Insect Conserv (in press)

Marhoul P, Dolek M (2012) Action plan for the conservation of the Danube Clouded Yellow Colias myrmidone in the European Union. European Commission, Brussels

Merckx T, Van Dyck H, Karlsson B, Leimar O (2003) The evolution of movements and behaviour at boundaries in different landscapes: a common arena experiment with butterflies. Proc R Soc Lond B Biol Sci 270:1815-1821

Nowicki P, Vrabec V (2011) Evidence for positive density-dependent emigration in butterfly metapopulations. Oecologia 167:657-665

Nowicki P, Witek M, Skorka P, Settele J, Woyciechowski M (2005) Population ecology of the endangered butterflies Maculinea teleius and $M$. nausithous and the implications for conservation. Popul Ecol 47:193-202

Örvössy N, Kőrösi Á, Batáry P, Vozár A, Peregovits L (2013) Potential metapopulation structure and the effects of habitat quality on population size of the endangered False Ringlet butterfly. J Insect Conserv 17:537-547

Petit S, Moilanen A, Hanski I, Baguette M (2001) Metapopulation dynamics of the bog fritillary butterfly: movements between habitat patches. Oikos 92:491-500

Rabasa G, Gutierrez D, Escudero A (2007) Metapopulation structure and habitat quality in modelling dispersal in the butterfly Iolana iolas. Oikos 116:793-806

Ricketts TH (2001) The matrix matters: effective isolation in fragmented landscapes. Am Nat 158:87-99

Schmitt T (2003) Influence of forest and grassland management on the diversity and conservation of butterflies and burnet moths (Lepidoptera, Papilionoidea, Hesperiidae, Zygaenidae). Anim Biodivers Conserv 26:51-67

Schtickzelle N, Mennenchez G, Baguette M (2006) Dispersal depression with habitat fragmentation in the bog fritillary butterfly. Ecology 87:1057-1065

Settele J, Kudrna O, Harpke A, Kühn I, van Swaay C, Verovnik R, Warren M, Wiemers M, Hanspach J, Hickler T, Kühn E, van Halder I, Veling K, Vliegenthart A, Wynhoff I, Schweiger O (2008) Climatic risk atlas of European butterflies. Pensoft, Sofia-Moscow

Shreeve TG, Dennis RLH (2011) Landscape scale conservation: resources, behaviour, the matrix and opportunities. J Insect Conserv 15(1-2):179-188

Sielezniew M (2012) Szlaczkoń szafraniec Colias myrmidone.. In: Makomaska-Juchiewicz M, Baran P (eds) Monitoring gatunków zwierząt. Przewodnik metodyczny. Część II. GIOŚ, Warszawa, pp 290-309

Sielezniew M, Nowicki P (2017) Adult demography of an isolated population of the threatened butterfly Scarce Heath Coenonympha hero and its conservation implications. J Insect Conserv 21:737-742

Sielezniew M, Wołkowycki M (2018) Pierwsza obserwacja dostojki akwilonaris Boloria aquilonaris w Puszczy Knyszyńskiej. Chrońmy Przyr Ojcz 74:215-219

Skórka P, Nowicki P, Lenda M, Witek M, Śliwińska EB, Settele J, Woyciechowski M (2013) Different flight behaviour of the endangered scarce large blue butterfly Phengaris teleius (Lepidoptera: 
Lycaenidae) within and outside its habitat patches. Landscape Ecol 28:533-546

Stevens VM, Pavoine S, Baguette M (2010a) Variation within and between closely related species uncovers high intra-specific variability in dispersal. PLoS ONE 5:e11123

Stevens VM, Turlure C, Baguette M (2010b) A meta-analysis of dispersal in butterflies. Biol Rev 85:625-642

Stevens VM, Trochet A, Van Dyck H, Clobert J, Baguette M (2012) How is dispersal integrated in life histories: a quantitative analysis using butterflies. Ecol Lett 15:74-86

Szentirmai I, Mesterházy A, Varga I, Schubert Z, Sándor LC, Ábrahám L, Kőrösi Á (2014) Habitat use and population biology of the Danube Clouded Yellow butterfly Colias myrmidone (Lepidoptera: Pieridae) in Romania. J Insect Conserv 18:417-425

Thomas CD, Hanski I (1997) Butterfly metapopulations. In: Hanski IA, Gilpin ME (eds) Metapopulation biology. Academic Press, London, pp 359-386

Turlure C, Baguette M, Stevens VM, Maes D (2011) Species-and sexspecific adjustments of movement behavior to landscape heterogeneity in butterflies. Behav Ecol 22:967-975
Van Swaay CAM, Warren MS, Lois G (2006) Biotope use and trends of European butterflies. J Insect Conserv 10:189-209

Van Swaay C. Cuttelod A, Collins S. Maes D. Munguira ML. Šašić M. Settele J. Verovnik R. Verstrael T. Warren M. Wiemers M, Wynhoff I (2010) European Red List of European Butterflies. Publication Office of the European Union, Luxembourg

Viljur M-L, Teder T (2016) Butterflies take advantage of contemporary forestry: clear-cuts as temporary grasslands. For Ecol Manag 376:118-125

Warren MS (1991) The successful conservation of an endangered species, the Heath fritillary butterfly Mellicta athalia in Britain. Biol Conserv 55:37-56

White GC, Burnham KP (1999) Program MARK: survival estimation from populations of marked animals. Bird Study 46:120-138

Publisher's Note Springer Nature remains neutral with regard to jurisdictional claims in published maps and institutional affiliations. 